\section{PENGARUH BIAYA PROMOSI TERHADAP PROFITABILITAS PADA PT. SIMPATIK CABANG GOWA}

\author{
Ardin \\ Universitas Pasifik Morota
}

\begin{abstract}
Abstrak. Tujuan penelitian ini adalah untuk 1). Menganalisis Pengaruh Biaya Promosi yang terdiri dari Periklanan, Promosi Penjualan, penjualan Personal dan Publisitas Terhadap Profitabilitas pada PT. Simpatik Cabang Gowa, dan 2). Menganalisis variabel yang paling dominan pengaruhnya terhadap Profitabilits pada PT. Simpatik Cabang Gowa. Penelitian ini dilaksanakan dengan jumlah populasi dan sampel yang sama dari data keuangan Perusahaan PT. Cabang Gowa untuk tiga tahun terakhir yang berarti berjumlah 36 bulan. Metode analisis yang digunakan adalah analisis metode klasik dan Regresi linear berganda dengan menggunakan program SPSS serie 20. Hasil penelitian melalui pengujian simultan menunjukkan bahwa variabel periklanan, variabel promosi penjualan, enjualan personal dan variabel publisitas berpengaruh positif dan signifikan terhadap variabel Profitabilitas, untuk pengujian secara parsial terhadap variabel promosi penjualan dan variabel penjualan personal menghasilkan pengaruh negatif dan berbanding terbalik terhadap profitabilitas Perusahaan PT. Simpatik Cabang Gowa. Selanjutnya secara parsial variabel periklanan menunjukkan pengaruh yang paling dominan terhadap profitabilitas dibandingkan dengan ke tiga variabel bebas lainnya.
\end{abstract}

Kata Kunci: Periklanan, Promosi Penjualan, Penjualan personal, Publisitas dan Profitabilitas

\section{INDONESIAN JOURNAL OF FUNDAMENTAL SCIENCES (IJFS)}

\section{E-ISSN: 2621-6728 \\ P-ISSN: 2621-671x}

Submitted: March $1^{\text {st }}, 2018$

Accepted : July, $3^{\text {th }}, 2018$

Abstract. The aims of the research are 1) To analyze the influence of cost promotion consisted of advertisement, sale promotion, Personal Sale and the publicity of the profitability of Simpatik in Gowa branch, and 2) To analyze the influence of the most dominant variable on the profitability of Simpatik in Gowa branch. The research was conducted by the same of population and sample taken from three years lately included thirty-six months by financing corporation data in Gowa branch. The method used was analyzes of classic method and doubled linear regression by using SPSS. 20. The result research through simultaneous testing showed that advertisement, sale promotion, personal sale and publicity variable gave the positive and significant influenced toward the profitability. Testing by partial way, the promotion and sale personality variable created negative influence and gave return equivalent toward the corporation of sale of Simpatik in Gowa branch. Next, in partial way, advertisement variable showed the most dominant influence toward profitability on the three of the others independent variable. 


\section{PENDAHULUAN}

Perusahaan didirikan bertujuan untuk meningkatkan volume penjualan, mempertinggi daya saing dan meminimalkan biaya produksi untuk mencapai laba maksimal. Perkembangan perusahaan dan laba yang dicapai perusahaan dapat digunakan sebagai alat ukur terhadap keberhasilan perusahaan dalam menjalankan aktivitas yang berkenaan dengan operasinya. Jika tujuan perusahaan itu tercapai maka kelangsungan hidup perusahaan dimasa yang akan datang tetap mampu dipertahankan dan mampu bersaing dengan perusahaan lain. Produsen harus selalu berusaha mengelola usahanya dengan baik guna mencapai tujuan tersebut. Banyak faktor yang mempengaruhi pencapaian tujuan tersebut, diantaranya adalah pemasaran. Dari sudut manajerial pemasaran adalah proses perencanaan dan pelaksanaan konsepsi, penetapan harga, promosi, distribusi gagasan, barang dan jasa untuk menciptakan pertukaran yang memuaskan tujuan individu dan organisasi (Kotler dan Keller, 2009, 38).

Persaingan ketat itu terlihat dari keadaan sekarang banyak perusahaan yang tidak mampu bersaing akan mengalami kerugian dan tutup dengan sendirinya, sementara perusahaan yang unggul dalam persaingan akan terus menguasai pasar. Setiap perusahaan, baik yang bergerak di bidang jasa maupun nonjasa, dalam melakukan kegiatan bisnis memerlukan strategi yang mampu menempatkan perusahaan pada posisi yang terbaik, mampu bersaing serta terus berkembang dengan mengoptimalkan semua potensi sumber daya yang dimiliki (Sitepu, 2005, 87). Agar tujuan perusahaan tercapai, perusahaan harus memperhatikan berbagai hal, bukan hanya masalah produksi barang atau jasa saja, tetapi juga harus memperhatikan masalah pasar, seperti memilih jenis barang atau jasa, menentukan harga barang atau jasa. Untuk mencapai tujuan tersebut perusahaan menjalankan berbagai cara seperti efisiensi biaya pemasaran, peningkatan hasil penjualan yang dapat dilakukan dengan cara menguasai pasar (perluasan pasar) walaupun biayanya diiringi berbagai macam resiko.

Meningkatnya penjualan serta cara-cara pemasaran merupakan faktor penentu untuk dapat mengetahui besar kecilnya laba usaha yang diperoleh perusahaan, sedangkan besar kecilnya laba perusahaan dapat dipengaruhi oleh harga pokok, biaya pemasaran serta banyaknya barang yang dijual oleh perusahaan tersebut. Untuk meningkatkan hasil penjualan dalam usaha memperoleh laba yang diinginkan maka sebaiknya perusahaan memperhatikan hal-hal yang berkaitan dengan usaha meningkatkan jumlah barang yang dijual (Rafiandi N. 2003, 215). Sebagaimana diketahui bahwa perusahaan merupakan suatu organisasi masyarakat dengan motivasi mencapai keuntungan atau laba maka perhatian manajemen semula dipusatkan pada bidang produksi, tetapi dengan semakin meningkatnya persaingan memperebutkan pasar. Bagian penjualan serta cara-cara pemasaran merupakan faktor penentu untuk dapat mengetahui besar kecilnya laba usaha yang diperoleh perusahaan, sedangkan besar kecilnya laba perusahaan dapat dipengaruhi oleh harga pokok, biaya pemasaran serta banyaknya barang yang dijual oleh perusahaan tersebut.

Untuk meningkatkan hasil penjulan dalam usaha memperoleh laba yang diinginkan maka sebaiknya perusahaan memperhatikan hal-hal yang berkaitan 
dengan usaha meningkatkan jumlah penjualan bergeser kepemasaran produknya, karena kegiatan produksi saja tidak akan menjamin menghasilkan laba, jika pemasaran produknya tidak mampu merebut pasar. Oleh karena itu manajemen perusahaan yang semula memusatkan perhatian pada bidang produksi, mulai memperluas perhatiannya pada bidang pemasaran produknya, namun akan menanggung biaya yang disebut biaya pemasaran. Untuk mendukung peluncuran produk manajemen prusahaan dapat melahirkan kiat-kiat alternatif (startegi) dalam mensiasati pasar dan salah satunya adalah promosi yang dapat digunakan untuk memperkenalkan produk yang dihasilkan. Suatu produk barang atau jasa harus diketahui oleh konsumen dan hal ini memerlukan proses awal dalam program promosi yaitu membangun presepsi yang menyentuh indra manusia. Presepsi inilah yang menentukan nasib produk itu sendiri dan keberhasilan perusahaan, apakah akan terus bertambah atau malah menurun dari kanca industri. Promosi yang merupakan salah satu alat paling umum untuk menciptakan komunikasi dua arah antara perusahaan dan konsumen sasarannya. Perusahaan dapat menggunakan alat promosi (iklan, promosi penjaulan, personel selling, dan publisitas) sebagai sarana untuk melayani konsumen yang memerlukan informasi mengenai produk yang dibutuhkan atau diinginkannya. Secara ringkas dapat dikatakan bahwa promosi adalah untuk menyampaikan informasi mengenai produk kepada konsumen yang harus dilakukan secara efektif dan efisien (Jefkin, 2000).

Konsumen sangat memerlukan informasi untuk menentukan keputusan suatu produk yang akan mereka beli di pasaran. Keputusan yang selalu diharapkan oleh produsen, apakah pesan yang disampaikan lewat promosinya telah dapat menjangkau pasar yang telah diharapkan atau belum. Apabila telah menjangkaunya berarti mencerminkan keberhasilan promosinya dan sudah tentu akan meningkatkan permintaan konsumen. Suatu perusahaan memproduksi barang dengan kualitas yang baik, harga relatif murah dibandingkan pesaing, dan tersebar ke berbagai tempat tetapi apabila calon pembeli tidak diberi tahu adanya produk tersebut, diingatkan atau dibujuk untuk membelinya maka produk tersebut tidak akan bisa laku dipasaran dan segala sesuatu yang dilakukan akan sia-sia. Perusahaan yang baru berdiri pun harus mempromosikan produknya untuk memberitahukan bahwa ada produk baru dan promosi yang perlu ditekankan adalah promosi yang sifatnya membujuk. Promosi yang sifatnya mengingatkan dilakukan terutama untuk mempertahankan merk dan image produk di hati konsumennya. Uraian tersebut menggambarkan betapa kompleksnya masalah promosi dalam suatu perusahaan, betapa pentingnya sistem dan strategi yang tepat dalam menyampaikan pesan kepada konsumen melalui berbagai media promosi. Kegiatan promosi yang dilakukan agar tujuan dari perusahaan dapat tercapai pastinya membutuhkan biaya. Biaya-biaya ini disebut dengan biaya promosi. Biaya promosi dikeluarkan oleh perusahaan antara lain untuk membuat pameran produk, memberi sponsor dan membuat iklan di media cetak maupun media elektronik. Sudah pasti perusahaan ingin selalu meningkatkan jumlah penjualan untuk mendapatkan laba yang lebih besar, dan dapat dilihat betapa berperannya promosi dalam upaya untuk mencapai tujuan perusahaan yaitu meningkatkan laba. 


\section{METODE PENELITIAN}

Metode penelitian yang digunakan analisis deskriptif adalah suatu metode analisis yang dilakukan dengan mengumpulkan data-data yang diperlukan, kemudian data-data tersebut diklasifikasikan, dianalisis, dan diinterpretasikan secara objektif sehingga diperoleh gambaran yang jelas mengenai topik ataupun masalah yang diteliti. Metode penelitian ini terdiri dari dua variabel, yaitu variabel independen (bebas) dan variabel dependen (terikat). Dapat diketahui bahwa variabel merupakan suatu atribut atau sifat atau nilai dari orang, obyek atau kegiatan yang mempunyai variasi tertentu yang ditetapkan oleh peneliti untuk dipelajari dan ditarik kesimpulannya.

Penelitian ini dilaksanakan pada PT. Simpatik Cabang Gowa dengan obyek penelitian adalah pengumpulan data berupa laporan biaya promosi dan laba yang diperoleh perusahaan PT. Simpatik Cabang Gowa. Waktu penelitian ini dilaksanakan pada bulan Desember 2014 sampai dengan bulan Februari 2015. Data kuantitatif yaitu data atau informasi yang diperoleh dalam bentuk angka-angka dan masih perlu dianalisis kembali, seperti jumlah, dan data lainnya yang menunjang penelitian tersebut. Sumber data yang digunakan dalam penelitian berupa data sekunder yaitu data penelitian yang diperoleh secara langsung dilapangan dan dicatat berupa laporan keuangan PT. Simpatik Cabang Gowa. Sumber data sekunder merupakan data yang diperoleh dari catatan-catatan, buku-buku, makalah, laporan, arsip dan dokumen lainnya yang berkaitan dengan penelitian ini.

Metode pengumpulan data yang digunakan dalam penelitian ini adalah sebagai berikut 1) observasi merupakan teknik pengumpulan data melalui pengamatan langsung terhadap variabel biaya periklanan, biaya promosi penjualan, biaya penjualan personal dan laporan laba untuk memperoleh data yang berhubungan dengan penelitian ini. 2) dokumentasi merupakan teknik pengumpulan data dengan mempelajari dokumen-dokumen, laporan dan informasi yang berkaitan dengan penelitian.

\section{HASIL DAN PEMBAHASAN}

Dari hasil pengujian hipotesis baik secara simultan maupun secara parsial, menunjukkan bahwa Biaya promosi yang telah dilakukan perusahaan yang terdiri dari Biaya Periklanan, Biaya Promosi Penjualan, Biaya Penjualan Personal dan Biaya Publisitas berpengaruh positif dan signifikan terhadap Profitabilitas Pada PT. Simpatik Cabang Gowa.

\section{Pengaruh Periklanan terhadap Profitabilitas}

Berdasarkan hasil uji parsial dengan menggunakan uji-t menunjukkan bahwa variabel Periklanan berpengaruh positif dan signifikan terhadap variabel Profitabilitas Pada PT. Simpatik Cabang Gowa yang berarti bahwa jika terjadi peningkatan dalam variabel Periklanan maka akan meningkatkan Profitabilitas. Variabel Periklanan memberikan pengaruh signifikan terhadap Profitabilitas dan menempati urutan pertama dari variabel bebas yang telah diuji. Karena itu variabel Periklanan merupakan salah satu faktor penting dalam meningkatkan Profitabilitas sehingga perlu dipertahankan dan ditingkatkan dengan tidak melupakan variabel yang lain 
dalam efisiensi Biaya Promosi untuk dapat meningkatkan tingkat Profitabilitas Pada PT. Simpatik Cabang Gowa.

Berdasarkan analisa tersebut, maka dapat disimpulkan bahwa variabel Periklanan berpengaruh positif dan signifikan terhadap variabel Profitabilitas. Oleh karena itu, Periklanan perlu dipertahankan terutama pada indikator yang membentuknya agar profitabilitas pada PT. Simpatik Cabang Gowa kelak dikemudian hari dapat lebih ditingkatkan. Hasil penelitian ini membuktikan bahwa penelitian yang dilakukan oleh Putri E. R (2008), bahwa Periklanan memberikan pengaruh positif dan signifikan terhadap Profitabilitas pada PT. KMK Plastics Indonesia. Demikian juga dengan penelitian Widyana J. M (2014), bahwa Periklanan memberikan pengaruh positif dan signifikan terhadap Profitabilitas pada PT UD Surya Logam Desa Temukus Tahun 2010-2012.

\section{Pengaruh Promosi Penjualan terhadap Profitabilitas.}

Hasil pengujian secara parsial diperoleh kejelasan bahwa variabel Promosi Penjualan menghasilkan nilai negatif sehingga pengaruhnya berbanding terbalik terhadap profitabilitas pada PT. Simpatik Cabang Gowa. Hubungan berbanding terbalik ini terjadi karena Perusahaan mengeluarkan kebijakan untuk mengurangi biaya promosi penjualan yang dianggap tidak terlalu berpengaruh terhadap peningkatan Profitabilitas Pada tahun berikutnya setelah biaya promosi penjualan ini dikurangi, ternyata dapat mendongkrak kenaikan tingkat profitabilitas dimana variabel yang lain dianggap konstan.

Penelitian ini tidak mendukung hasil penelitian terdahulu, seperti Putri (2008), yang hasilnya menyatakan bahwa Promosi Penjualan berpengaruh secara positif dan signifikan terhadap Profitbilitas pada PT. KMK Plastics Indonesia. Demikian juga dengan hasil penelitian Rustami (2014), yang menyatakan bahwa variabel Promosi Penjualan berpengaruh signifikan terhadap Variabel Profitabilitas pada Perusahaan PT. Kopi Banyuatis. Bedanya dengan penelitian ini dari segi produk, tempat maupun harga

\section{Pengaruh Penjualan Personal terhadap Profitabilitas}

Berdasarkan hasil pengujian secara parsial diperoleh kejelasan bahwa variabel penjualan personal menghasilkan nilai negatif sehingga pengaruhnya berbanding terbalik terhadap tingkat profitabilitas sehingga variabel penjualan personal berpengaruh dan tidak signifikan terhadap variabel Profitabilitas pada PT. Simpatik Cabang Gowa. Dengan demikian pihak perusahaan beranggapan bahwa tidak menemukan personal yang dianggap profesional dalam menjual. Oleh karena itu untuk jenis penjualan personal mendapat efisiensi biaya dari perusahaan.

Hasil penelitian ini membuktikan bahwa penelitian yang dilakukan oleh Putri (2008), bahwa Penjualan Personal memberikan pengaruh positif dan signifikan terhadap Profitabilitas pada PT. KMK Plastics Indonesia. Demikian juga dengan penelitian Widyana (2014), bahwa Penjualan Personal memberikan pengaruh positif dan signifikan terhadap Profitabilitas pada PT UD Surya Logam Desa Temukus Tahun 2010-2012.

\section{Pengaruh Publisitas terhadap Profitabilitas.}

Berdasarkan hasil Uji Parsial diperoleh hasil bahwa variabel Publisitas berpengaruh secara positif dan signifikan terhadap Variabel Profitabilitas. Hal ini 
dimaksudkan bahwa jika Variabel Publisitas ditingkatkan maka variabel Profitabilitas juga akan mengalami peningkatan. Variabel Publisitas menempati urutan ke dua dari empat variabel bebas dalam memberikan pengaruhnya secara positif dan signifikan terhadap variabel Profitabilitas sebagai variabel terikat. Karena itu variabel Publisitas perlu mendapat perhatian untuk selalu menjaga indicator yang membentuk variabel Publisitas agar dapat selalu memberikan kontribusi dalam meningkatkan variabel Profitabilitas.

Hasil penelitian ini membuktikan bahwa penelitian yang dilakukan oleh Putri (2008), bahwa Publisitas memberikan pengaruh positif dan signifikan terhadap Profitabilitas pada PT. KMK Plastics Indonesia. Demikian juga dengan penelitian Widyana (2014), bahwa Publisitas memberikan pengaruh positif dan signifikan terhadap Profitabilitas pada PT UD Surya Logam Desa Temukus Tahun 2010-2012. Demikian juga Rustami (2014), yang menyatakan bahwa variabel Publisitas berpengaruh signifikan terhadap Variabel Profitabilitas pada Perusahaan PT. Kopi Banyuatis.

\section{Hasil Uji Asumsi Klasik}

Hasil uji asumsi klasik juga membuktikan bahwa model regresi memenuhi persyaratan karena terbukti data-data yang digunakan dalam analisis berdistribusi normal dan tidak terjadi gejala multikolinearitas, heteroskedastisitas dan autokorelasi (hasil pada pembahasan uji asumsi klasik). Berdasarkan analisis penelitian ini maka yang berpengaruh secara nyata terhadap profitabilitas yaitu periklanan ( $\mathrm{X}_{1}$ ) berpengaruh positif signifikan, promosi Penjualan (X2) berpengaruh positif signifikan, penjualan personal $\left(\mathrm{X}_{3}\right)$ berpengaruh positif signifikan, dan publisitas (X4) berpengaruh positif signifikan.

Hasil penelitian ini membuktikan bahwa penelitian yang dilakukan oleh Putri (2008), bahwa Penjualan Personal memberikan pengaruh positif dan signifikan terhadap Profitabilitas pada PT. KMK Plastics Indonesia. Demikian juga dengan penelitian Widyana (2014), bahwa Penjualan Personal memberikan pengaruh positif dan signifikan terhadap Profitabilitas pada PT UD Surya Logam Desa Temukus Tahun 2010-2012.

\section{Rasio Profitabilitas Returen On Equity (ROE)}

Dari hasil analisa data mengenai rasio profitabilitas diperoleh hasil bahwa tingkat profitabilitas i menghasilkan angka rasio untuk tahun 2011 sebesar 20\% kemudian pada tahun 2012 mengalami penurunan menjadi 18\% sekalipun pada saat itu terjadi penambahan modal sendiri dan penambahan biaya promosi yang diharapkan dapat mengangkat tingkat perolehan laba, namun kenyataanya tidak memenuhi harapan, sehingga pada tahun berikutnya 2013 Perusahaan mengambil kebijakan mengurangi pengeluaran untuk biaya promosi khususnya promosi penjualan dan disisi lain pemegang saham menarik sebagain penempatannya dalam rangka efisiensi untuk mengembalikan tingkat perolehan laba yang sempat menurun tahun sebelumnya (2012). Ternyata pada tahun 2013 kebijakan efisiensi perusahaan menghasilkan kenaikan pendapatan laba hingga mencapai rasio profitabilitas sebesar $21 \%$. 


\section{KESIMPULAN}

Berdasarkan uraian dan hasil penelitian serta pembahasan yang dilakukan pada bagian sebelumnya, maka berikut ini dapat ditarik kesimpulan beberapa hal sebagai berikut: 1) dari hasil pengujian secara simultan atau serempak, menunjukan bahwa pengaruh Biaya Promosi (variabel Periklanan, variabel Promosi Penjualan, variabel Penjualan Personal dan variabel Publisitas) berpengaruh secara positif dan signifikan terhadap variabel Profitabilitas pada Perusahaan PT. Simpatik Cabang Gowa. 2) dari hasil analisis secara parsial, diperoleh adanya kenyataan bahwa dari empat variabel dalam Biaya Promosi dua diantaranya yaitu periklanan dan publisitas masing-masing berpengaruh positif dan signifikan terhadap variabel profitabilitas sedangkan variabel promosi penjualan dan penjualan personal ternyata memberikan hasil negatif yang berarti bahwa pengaruh kedua variabel itu terhadap profitabilitas adalah berbanding terbalik artinya bila kedua variaber negatif ini bertambah negatifnya (semakin menurun) maka profitabilitasnya akan semakin bertambah.

\section{DAFTAR PUSTAKA}

Angga Cakra Noviya R. (2012). Pengaruh Biaya Pemasaran Terhadap Laba Operasional (Studi Kasus Pada Perusahaan Makanan Lintang Tasikmalaya). Tesis. Fakultas Ekonomi Universitas Siliwangi.

Arnando, Wily. (2010). Analisis Bauran Promosi Dalam Meningkatkan Penjualan Mobil Toyota di Padang, Tesis Jurusan Ekonomi Unand.Assauri, Sofjan, Manajemen Pemasaran (dasar konsep dan strategi) Edisi 6, Penerbit PT. Raja Grafindo Persada, Jakarta: 2009.

Assauri, Sofjan. (2001). Manajemen Pemasaran Dasar, Konsep dan Strateg. Edisi Kedua. Rajawali. Jakarta.

Assauri, Sofjan. (2011). Manajemen Pemasaran. Cetakan 11, PT. Raja Grafindo Persada. Jakarta.

Basu Swastha DH, Irawan. (2002). Azas-Azas Marketing. Akademi Keuangan dan Bisnis (AKB). Yogyakarta.

Dwijayanti, Ery Septia. (2010). Pengaruh Diskon dan Biaya Iklan terhadap Volume penjualan, Study kasus pada Steak orange. Tasikmalaya : Universitas Siliwangi.

Enda Suhenda. (2001). Pengaruh Biaya Pemasaran Terhadap Efektivitas Pencapaian Laba (Studi Kasus Pada PT. Pos Indonesia KAWILPOS V Bandung). Tesis Program Studi Akuntansi Fakultas Ekonomi Universitas Pasundan Bandung.

Ferdinand, Augusty. (2013). Metode Penelitian Manajemen. Edisi 4. Badan Penerbit Universitas Diponegoro. Semarang.

Jefkins, Frank. (1997). Periklanan. Erlangga. Jakarta.

Jefkins, Frans. (2000). Periklanan. Edisi kelima Terjemahan Haris Munandar. Erlangga. Jakarta.

Kotler, Philip dan Molan, Benyamin. (2000). Manajemen pemasaran, jilid 1 Edisi milenium: Pemasaran Dari The Prentice Hall International. Prenhalindo. Jakarta. 
Kotler, Philip and Kaller K. L. (2009). Manajemen Pemasaran, Ahli Bahasa: Beyamin Molan; Manajemen Pemesaran, Edisi 12. Erlangga. Surabaya.

Kotler, Philip. (2003). Manajemen Pemasaran Analisis Planning Kontrol,

Modding, Basri. (2012). Pemasaran Strategik, Edisi 1, Cetakan 1, PT. Umitoha Ukhuwah Grafika, Makassar.

Peter J.P., and Jerry C.O. (2013). Perilaku Konsumen dan Strategi Pemasaran, Edisi 9, Buku 1, Salemba empat, Jakarta.

Pujiyanto. (2001). Periklanan, Malang: Universitas Negeri Malang.

Putri wulandari. (2013). Pengaruh Perubahaan Pendapatan Penjualan Tiket Pesawat dan Kapal Pelni Terhadap Perubahaan Laba Perusahaan Pada PT. Pesona Bintan Tours \& Travel. Tesis Fakultas Ekonomi Universitas Maritim Raja Haji (UMRAH) Tanjungpinang.

Radio Sunu. (1998). Manajemen Pemasaran Suatu Pendekatan Analisis. edisi Kedua. BPFE. Yogyakarta.

Rafiandi Nazar. (2003). Analisis Laba Berdasarkan Penjualan Tunai Dan Penjualan Kredit Pada Kantor Pusat Pt Columbus Megah Sentrasarana Di Berau. eJournal Ilmu Administrasi Bisnis, 2013, 1 (3): 214-224 ISSN 0000-0000, ejournal.adbisnis.fisip-unmul.org @ Copyright 2013.

Salvatore, Dominick. (2005). Managerial Economics : Ekonomi Manajerial dalam Perekonomian Global. Jakarta : Salemba Empat.

Sitepu, Masliana Bangun. (2005). Mengatasi Berbagai Tantangan dalam Era Globalisasi melalui Peningkatan Perilaku Kewiraswastaan. Jurnal Ilmu Administrasi dan Organisasi, Bisnis \& Birokrasi, Vol.13, No.1 (Januari).

Sugiono. (2010). Statistika untuk Penelitian, Cetakan kesembilan, Alfabeta, Bandung.

Sutarya Dewi Wulansari. (2012). Pengaruh Pengendalian Biaya Produksi dan Biaya Pemasaran Terhadap Laba Operasional (Studi Kasus Pada PD.Anggraeni Tasikmalaya). Tesis Program Studi Akuntansi Fakultas Ekonomi Universitas Siliwangi.

Swastha Basu dan Ibnu Sukotjo. (2000). "Pengantar Bisnis Modern", Edisi Ketiga Yogyakarta: Liberty.

Tuanakotta. (2000). Teori Akuntansi, Buku 2, Lembaga Penerbit Fakultas Ekonomi UI , Jakarta.

Tjiptono, Fandy, dan Gregorius Chandra. (2012). Pemasaran Strategik, Edisi 2, Andi, Yogyakarta.

William J. Stanton. (2006). Prinsip Pemasaran, Terjemahan Sadu Sundaru, Edisi Ketujuh, Erlangga : Jakarta. 